\title{
Physicochemical and microbiological stability of fermented dairy beverages added with red rice extract
}

\author{
Josianny Alves BOÊNO ${ }^{1 *}$ (D), Edmar Soares NICOLAU², Diego Palmiro Ramirez ASCHERI ${ }^{3}$
}

\begin{abstract}
Fermented dairy beverages added with red rice extract and whey were the developed, physicochemical and microbiological properties were evaluated. A central composite rotatable design was applied, using nine treatments with three replicates. The $\mathrm{pH}$ indicated that the beverages could be consumed without the addition of preservative for up to 28 days of storage. The beverages are characterized as partially skimmed, with high protein content, zinc, manganese and copper levels, similar potassium and iron levels and low sodium, magnesium and calcium levels, if compared to the recommended daily index. The absence of pathogens and numbers of viable lactic acid bacteria above the established minimum level were observed. The physicochemical parameters were evaluated by ANOVA and PCA, grouping the beverages into four groups according to their physicochemical properties and three groups according to mineral levels. It is suggested that the most adequate treatments contain between 20 and $34 \%$ of red rice extract and from 26 to $54 \%$ of whey because of their lower copper contents.
\end{abstract}

Keywords: nutritional quality; microbiology; shelf life; stability; whey.

Practical Application: Development of dairy beverages add red rice extract, without gluten and high protein.

\section{Introduction}

Whey is no longer a waste of cheese-making but a raw material for value-added products including probiotic beverages. According Pescuma et al. (2010) whey is composed of water, lactose, proteins, fat and minerals $(93,5,0.85,0.36$ and $0.53 \mathrm{~g}$ per $100 \mathrm{~g}$ of milk, respectively) as well as lactic acid $\left(0.5 \mathrm{~g} \mathrm{~L}^{-1}\right)$, and other compounds, and offers a suitable food matrix for the growth and viability of probiotic microorganisms. However, because of its high nutritional value, whey is an attractive by-product for use as a supplement in human food. Thus, whey constitutes a good raw material for the development of new dairy products.

Whey may be used directly or may be supplemented with dairy based powders (i.e. buttermilk powder, skim milk powder, etc.) or added to beverage formulations at varying ratios. (Turkmen et al., 2019). In addition, different technologies can be used in whey to aid in their use in the food industry, such as ohmic heating (Costa et al., 2018; Cappato et al., 2018) and ultrasound processing (Guimarães et al., 2018).

The whey based beverages are usually manufactured with at least $51 \%$ (mass/ mass) of the ingredients consisting of dairy compounds (fluid or powdered milk and whey). Despite the low cost of production, the whey has excellent nutritional and functional properties (Yadav, et al., 2015; Brandelli et al., 2015), and its nutritional and functional values could be further enhanced by incorporation of other ingredients such as fruit pulps, prebiotics and vegetable extracts (Granato et al., 2018a; Guimarães et al., 2019).
Although limited, probiotic beverage formulations including fruit juices or pulps are available in the global markets. These ingredients helps improving the sensory acceptability of the products (Turkmen et al., 2019) but the type of fruit affected the growth and viability of probiotic bacteria in the beverages (Arsic et al., 2018). According Granato et al. (2018a) herbal extracts not only improve the sensory and nutritional properties and color of yogurts but also improve the stability of microorganisms in the course of refrigerated storage. Still, the use of herbal preparations not only increases the bioactive compounds and antioxidant activity of yogurts and fermented milks but also increases considerably the sensory acceptance of these new foods.

The fermented dairy beverages have contents of lactic acid, galactose, free amino acids, fatty acids and vitamins (especially B complex), improvement of lactose tolerance, enhanced absorption of nutrients (including minerals) (Buttriss, 2010). The bioavailability of minerals such as calcium, zinc, iron, manganese, copper and phosphorus can be increased through the production of lactic acid, with consequent reduction of the gastric $\mathrm{pH}$. Regarding vitamins, there is an increase in the concentration of folic acid, niacin and riboflavin (Tamime \& Robinson, 2007).

Red rice, also known as Bhutanerse red rice and weedy rice, and known in Brazil as "arroz vermelho", "arroz-de-Veneza" and "arroz-da-terra" (Pereira et al., 2009), belongs to the same botanic species as white rice (Oryza sativa L.) and is rich in functional compounds, fibers and minerals (Ascheri et al., 2012). Red rice 
plant extract can be used for the preparation of new fermented dairy beverage products with different sensory characteristics such as color, odor, texture, taste and nutritional composition.

This type of colored rice has contents of carbohydrates, proteins, lipids, minerals and fibers of approximately $78,7,2,1$ and $3 \mathrm{~g}$ per $100 \mathrm{~g}$ of rice (dry basis), respectively, with a caloric value of approximately $361 \mathrm{kcal}$ per $100 \mathrm{~g}$ of red rice (Ascheri et al., 2012). Red rice has antioxidant activity as a result of its high polyphenol content (Itani \& Ogawa, 2004) and red rice is gluten-free.

Considering that whey with great nutritional and functional benefits and that alternative uses of these nutrients might increase the value of dairy production and reduce the environmental damage, differentiated fermented dairy beverages based on whey and red rice extract that could be consumed by celiac patients, because red rice is gluten-free, were developed in the present study. The purpose of this study was to evaluate the physicochemical and microbiological properties of fermented dairy beverages prepared with different proportions of whey as substitute for milk in the dairy base and with red rice extract.

\section{Materials and methods}

The whole milk used was within the normal standards for the preparation of dairy beverage. The whey obtained by production of Minas frescal cheese was characterized as being sweet with $\mathrm{pH} 6.6$, acidity of $0.11 \mathrm{~g} / 100 \mathrm{~g}$ of lactic acid and total solids content of $6.86 \%$. According to these characteristics, the milk and whey were considered good raw materials for the preparation of fermented dairy beverages according NI $\mathrm{N}^{\circ} 62$ (Brasil, 2011) and $\mathrm{N}^{\circ} 53$ (Brasil, 2013a).

The whole, pasteurized, homogenized milk, the natural yogurt containing Streptococcus thermophillus and Lactobacillus bulgaricus (Nestlé, Brazil) sucrose and the stabilizer (GFG of brand RICANATA, Brazil) and red rice were obtained in the local market of Morrinhos (GO, Brazil). The whey was obtained by milk coagulation according Furtado \& Neto (1994).

The red rice extract was produced by microwave cooking. Initially, the rice was grinded in an industrial blender at a ratio of five parts of water to one part of rice $(5: 1 \mathrm{v} / \mathrm{w})$, followed by heating in a microwave (Eletrolux, MEF41, Brazil) at high power $(1000 \mathrm{~W})$ until the sample reached the temperature of $85{ }^{\circ} \mathrm{C}$, recorded using a handheld thermometer. The cooked extract was mixed in a blender for two min until it reached a smooth consistency.

The fermented dairy beverages were prepared with red rice extract as the basis and the substitution of milk by whey. The experiment was performed using a $2^{2}$ central composite rotatable design with four axial points and three replicates at the central point, for the microbiological analyses. For the remaining analyses, three replicates were performed not only at the central point but also in each of the nine treatments, to study the effects on the physicochemical properties of the beverages (Table 1). The whey levels varied from 26 to $54 \%$ [dairy base, which is $51 \%$ according Brasil (2005a), and red rice extract varied from 6 to $34 \%$.

To prepare each treatment experimental in fermented dairy beverages was used $0.3 \%$ of stabilizer, $10 \%$ of sucrose and $2.5 \%$ of natural yogurt and the amount of red rice extract stipulated. The total dairy base was calculated by discounting $100 \%$ of all raw materials used. The regulation of identity and quality of dairy drinks (Brasil, 2005a), does not bring a definition of "dairy base", but according to Masson et al. (2011) it corresponds to the sum of milk and whey. However, a maximum concentration of whey to be substituted for milk in the dairy base is not established, so the limit for this substitution is regulated by the protein content of the mixture, which for fermented beverages with $1.0 \%$ (Brasil, 2005a).

From then on, it was calculated with different proportions of milk-replacing whey as stipulated in each treatment, as shown in Table 1.

Except for the natural yogurt, the other ingredients were manually mixed in polyethylene containers with hermetic lids. The thermal treatment was performed in water bath (Quimis, Q334M-28, Brazil) at $65^{\circ} \mathrm{C}$ for $30 \mathrm{~min}$. After heating, the containers were chilled until $45^{\circ} \mathrm{C}$ and treated with the natural yogurt.

The fermentation of the beverages occurred at the same temperature of $45^{\circ} \mathrm{C}$ until reaching a $\mathrm{pH}$ of $4.5(\sim 5 \mathrm{~h})$ as measured with a bench top $\mathrm{pH}$ meter (Tecnopon, MPA210, Piracicaba, Brazil). After fermentation, the containers were chilled in a refrigerator (Consul, Duplex CRD45, Brazil) at $8{ }^{\circ} \mathrm{C}$ for $12 \mathrm{~h}$. The dairy beverages fermented as such were homogenized,

Table 1. Codified and real values of the variables red rice extract (RRE) and whey (W) applied in the elaboration of the fermented dairy beverages.

\begin{tabular}{|c|c|c|c|c|c|c|c|}
\hline \multirow{2}{*}{ Treatment } & \multicolumn{2}{|c|}{ Coded variables } & \multicolumn{2}{|c|}{ Real variables } & \multirow{2}{*}{$\begin{array}{c}\begin{array}{c}\text { Total Dairy Base } \\
\text { (Milk: Whey) }\end{array} \\
(\%)\end{array}$} & \multirow{2}{*}{$\begin{array}{c}\text { Milk } \\
\mathrm{g} / 100 \mathrm{~g}\end{array}$} & \multirow{2}{*}{$\begin{array}{l}\text { Whey } \\
\text { g/100g }\end{array}$} \\
\hline & RRE & $\mathrm{W}$ & RRE (\%) & W (\%) & & & \\
\hline $\mathrm{T} 1$ & -1 & -1 & 10 & 30 & $77.2(70: 30)$ & 54.0 & 23.2 \\
\hline $\mathrm{T} 2$ & 1 & -1 & 30 & 30 & $57.2(70: 30)$ & 40.0 & 17.2 \\
\hline $\mathrm{T} 3$ & -1 & 1 & 10 & 50 & $77.2(50: 50)$ & 38.6 & 38.6 \\
\hline $\mathrm{T} 4$ & 1 & 1 & 30 & 50 & $57.2(50: 50)$ & 28.6 & 28.6 \\
\hline $\mathrm{T} 5$ & -1.41 & 0 & 6 & 40 & $81.2(60: 40)$ & 48.7 & 32.5 \\
\hline T6 & 1.41 & 0 & 34 & 40 & $53.2(60: 40)$ & 31.9 & 21.3 \\
\hline $\mathrm{T} 7$ & 0 & -1.41 & 20 & 26 & $67.2(74: 26)$ & 49.7 & 17.5 \\
\hline $\mathrm{T} 8$ & 0 & 1.41 & 20 & 54 & $67.2(46: 54)$ & 30.9 & 36.3 \\
\hline T9 & 0 & 0 & 20 & 40 & $67.2(60: 40)$ & 40.3 & 26.9 \\
\hline
\end{tabular}


individually, in a blender and placed again in the containers stored in a horizontal freezer (Consul, CHB53, Brazil) at $5{ }^{\circ} \mathrm{C}$ until the time of the analyses.

A second experiment was performed with completely randomized design and a $9 \times 8$ factorial arrangement ( 9 beverage formulations, 8 times) with three replicates. From the first day of preparation of the beverages and at 7-day intervals until the end of the storage period (56 days), the $\mathrm{pH}$ data were recorded, in triplicate, and used to create line plots. The physicochemical quality (titratable acidity, protein content (with conversion factor of 6.38), ashes, total solids, lipids, lactose, carbohydrates and energy value) and microbiological quality of the developed fermented dairy beverages were evaluated from the first day of preparation and at the $20^{\text {th }}$ and $40^{\text {th }}$ day of storage were determined according to Association of Official Analytical Chemists (2005).

The $\mathrm{pH}$, titratable acidity, lipids, total solids and ashes were analyzed in the milk and whey according to Association of Official Analytical Chemists (2005). In red rice, the moisture and protein levels and the manganese $(\mathrm{Mn})$, zinc $(\mathrm{Zn})$ and iron $(\mathrm{Fe})$ contents were determined according to Association of Official Analytical Chemists (2005).

Carbohydrates content was calculated by the percentage difference of the sum of proteins, lipids, ashes and moisture. The energy value of the beverages prepared was calculated using the following conversion factors: $4.0 \mathrm{kcal} \mathrm{g}^{-1}$ for protein and carbohydrates and $9.0 \mathrm{kcal} \mathrm{g}^{-1}$ for lipids (Brasil, 2003a).

The macro-elements sodium $(\mathrm{Na})$, potassium $(\mathrm{K})$, calcium (Ca) and magnesium $(\mathrm{Mg})$ and the micro-elements $\mathrm{Fe}, \mathrm{Mn}$, $\mathrm{Zn}$ and copper $(\mathrm{Cu})$ were also analyzed in the fermented dairy beverages stored for 40 days, according to Association of Official Analytical Chemists (2005). The $\mathrm{Ca}, \mathrm{Mg}, \mathrm{Fe}, \mathrm{Mn}, \mathrm{Zn}$ and $\mathrm{Cu}$ values were measured in an atomic absorption spectrophotometer (Perkin Elmer, 5100 PC, Waltham, MA, USA), whereas a flame photometer was used for $\mathrm{Na}$ and $\mathrm{K}$ (Corning 400, Cambridge, United Kingdom). The concentration of the minerals was compared with the recommended daily intake (RDI) for adults, established by RDC 269 of 09/22/05 Brasil (2005b).

The hygienic-sanitary quality of the fermented dairy beverages was evaluated at 0,20 and 40 days of storage under refrigeration at $5{ }^{\circ} \mathrm{C}$, through the detection of the presence of total coliforms $\left(\right.$ at $\left.35^{\circ} \mathrm{C}\right)$ and thermotolerant coliforms $\left(45^{\circ} \mathrm{C}\right)$, according to the methodology recommended by the American Public Health Association (American Public Health Association, 2001), assessing its conformity with the Standards of Identity and Quality for Dairy Beverages (Brasil, 2005a) and Brasil (2001).

Qualitative analyses of Salmonella spp. and coagulase-positive staphylococci were performed according to (American Public Health Association, 2001). The lactic acid bacteria were analyzed according to the method described by International Organization for Standardization (1998), using MRS agar culture medium.

The results from physicochemical, macro- and micro-element characterization experiments were analyzed using One-way ANOVA test, and the differences of averages were compared by Tukey test at $5 \%$ of significance level. And then the experimental results were organized into an array of treatments (in columns) and responses (in rows), and it was submitted to Principal Component Analysis (PCA) was applied as pattern recognition unsupervised classification method. PCA transforms the original, measured variables into new uncorrelated variables called principal components. The first principal component covers as much of the variation in the data as possible. The second principal component is orthogonal to the first and covers as much of the remaining variation as possible, and so on Patras et al. (2011). The number of dimensions to keep for data analysis was evaluated by the respective eigenvalues (which should be greater than one), by the Cronbach's alpha parameter (that must be positive) and also by the total percentage of variance (that should be as higher as possible) explained by the number of components selected. The number of dimensions considered for PCA was chosen in order to allow meaningful interpretations, to ensure their reliability Granato et al. (2018b). The results of the microbiological analysis were evaluated descriptively. Statistica software version 6.0 (Statsoft, 2007) was used for the statistical analysis of the data.

\section{Results and discussion}

The protein content (6.37\%) of red rice was close to the range reported by Rohman et al. (2014) for varieties of rice (6.02-7.94\%) and the range reported for the red rice genotypes (6.9 to $7.8 \%$ ) studied by Ascheri et al. (2012), but below the value (10.49\%) reported for the red rice by Raghuvanshi et al. (2017). Red rice provided one or more times the amount of $\mathrm{Zn}, \mathrm{Fe}$, and $\mathrm{Mn}$ (4.6, 0.68 , and $1.88 \mathrm{mg} / 100 \mathrm{~g}$, respectively) compared to white rice and red rice described by Sharma et al. (2012) and Raghuvanshi et al. (2017). These results demonstrate that red rice has the nutritional potential to enrich fermented dairy beverages.

At the beginning of the refrigeration of the dairy beverages prepared in the present study, the $\mathrm{pH}$ oscillated between 4.3-4.5 (Figure 1). At the $56^{\text {th }}$ day of storage, the $\mathrm{pH}$ decreased, remaining between 4.0 and 4.2. This is due to a post-acidification that affects the metabolism of microorganisms, where acidity occurs due to the continued production of lactic acid by dairy bacteria present in these products (Lourens-Hattingh \& Viljoen, 2001).

The analysis of the $\mathrm{pH}$ variation is important because it is related to the sensitivity to sensory changed during storage. According to Zacarchenco \& Massaguer-Roig (2004), pH variations between 0.14 and 0.32 correspond to sensorially perceptible decreases, whereas $\mathrm{pH}$ variations lower than 0.12 are imperceptible decreases. Figure 1 indicates that treatments T5 to T7 and T9 to T11 showed perceptible decreases at 28 days of refrigeration, whereas treatments T3, T4 and T8 showed this decrease at 42 days, and $\mathrm{T} 1$ and $\mathrm{T} 2$ showed it at 49 and 21 days, respectively. These observations suggest that to guarantee the shelf life of beverages developed with no addition of preservatives, the $\mathrm{pH}$ variations should maintain an acceptable value during the refrigeration period, and beverages must be kept under optimal temperature, transportation and storage conditions. Then according to studies by Zacarchenco \& Massaguer-Roig (2004) developed beverages in this study should be consumed up to 28 days after their preparation so that their $\mathrm{pH}$ changes with the refrigeration time are not perceived by the consumers. 
The developed beverages should be consumed up to 28 days after their preparation so that their $\mathrm{pH}$ changes with the refrigeration time are not perceived by the consumers.

The fermented dairy drinks, in general, showed significant differences about to the physical-chemical characteristics, macro and micro-elements (Table 2). With the exception of the protein and magnesium contents, all of the other constituents show significant differences in at least one comparison between treatments according to the Tukey's test.
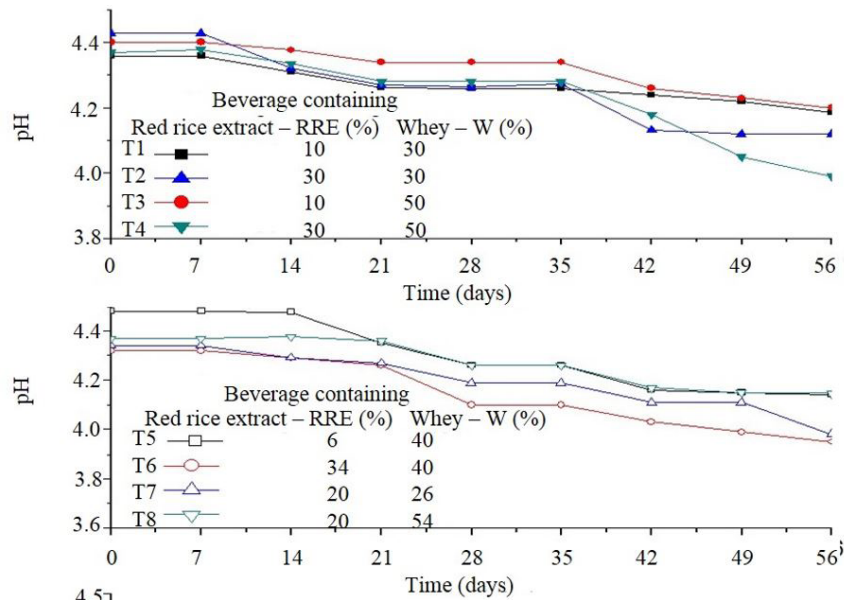

这

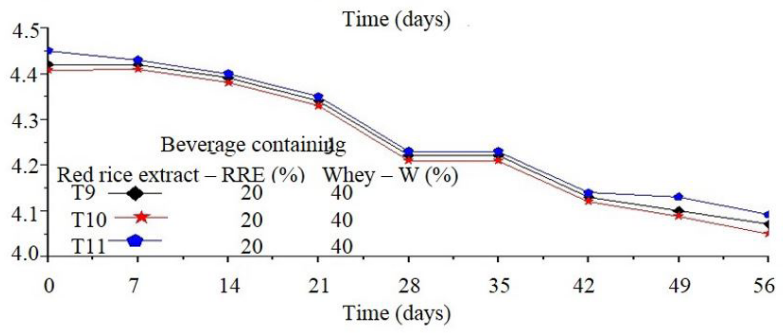

Figure 1. Mean $\mathrm{pH}$ values of the different treatments of fermented dairy beverages augmented with red rice flour extract at different storage times.
The titratable acidity values comply with the Brazilian legislation (Brasil, 2007) that establishes values between 0.6-2.0 g per $100 \mathrm{~g}$ of lactic acid and are similar to the values determined in yogurt fortified with carrot powder $(0.94 \mathrm{~g}$ per $100 \mathrm{~g}$ of lactic acid) by Madora et al. (2016). The ash content varied between 0.47 and $0.59 \%$ and was lower than the values determined by Bakr et al. (2017) in rice-based strawberry yogurt (0.26\%). The total solids varied between 20.7 and $22.7 \%$, and the values were higher than those found by Cunha et al. (2008) in fermented dairy beverages (18.08 and $19.44 \%$ ). The protein content varied between 1.98 and $2.06 \%$ similar to those found by Tarantola \& Wujastyk (2009) in rice-based commercial beverages.

The carbohydrate contents were between 16 and 19\%, which is similar to the values obtained by Tarantola \& Wujastyk (2009) in commercial, rice-based dairy beverages (10 and 35\%).

The prepared beverages showed lactose contents between 3.97 and $6.19 \%$, indicating that these beverages cannot be consumed by individuals with lactose malabsorption and by lactose-intolerant consumers because, according to Ferronato et al. (2004), fermented yogurt and milk can be consumed by such individuals if the products have on average 30\% less lactose than milk.

According to the lipid content, the prepared beverages are considered partially skimmed beverages for containing values lower than $2.9 \%$. The energy values of the beverages were was close to the range reported by Lima et al. (2016) for fermented dairy beverages prepared with different concentrations of whey and araticum pulp (between $85-93 \mathrm{kcal} 100 \mathrm{~g}$ ).

The addition of red rice extract to the produced beverages provided considerable $\mathrm{Zn}$ (2.5 to $6.83 \%), \mathrm{Mn}$ (2.13 to 6.33\%) and $\mathrm{Cu}$ (44.3 to $162 \%)$. Contain lower among of $\mathrm{Na}$ less than $70 \mathrm{mg}$ of $\mathrm{Na}$ per $100 \mathrm{~g}$ of sample. According to Ordinance SVS/MS N $27 / 1998$ (Brasil, 1998), the beverages elaborated in the

Table 2. Mean values for the physicochemical, macro and micro-element characterization of the fermented dairy beverages augmented with red rice extracts after different storage periods.

\begin{tabular}{|c|c|c|c|c|c|c|c|c|c|}
\hline Analyses & $\mathrm{T} 1$ & $\mathrm{~T} 2$ & T3 & $\mathrm{T} 4$ & T5 & T6 & T7 & T8 & T9 \\
\hline Titratable Acidity $^{1}$ & $0.62^{\mathrm{ab}}$ & $0.58^{\mathrm{bc}}$ & $0.54 \mathrm{c}$ & $0.54 \mathrm{c}$ & $0.55 \mathrm{c}$ & $0.56 \mathrm{c}$ & $0.64^{\mathrm{a}}$ & $0.56 \mathrm{c}$ & $0.56 c$ \\
\hline Ashes $^{1}$ & $0.58^{\mathrm{ab}}$ & $0.51^{\mathrm{c}}$ & $0.55^{\mathrm{b}}$ & $0.47^{\mathrm{d}}$ & $0.59^{\mathrm{a}}$ & $0.47^{\mathrm{d}}$ & $0.55^{\mathrm{b}}$ & $0.52^{\mathrm{bc}}$ & $0.53^{\mathrm{bc}}$ \\
\hline Total Sol. ${ }^{1}$ & $21.52^{\mathrm{d}}$ & $22.65^{a}$ & $20.57^{\mathrm{g}}$ & $22.40^{\mathrm{b}}$ & $20.66^{g}$ & $22.35^{\mathrm{b}}$ & $22.08^{\mathrm{c}}$ & $21.10^{\mathrm{f}}$ & $21.36^{\mathrm{e}}$ \\
\hline Protein $^{1}$ & $2.06^{\mathrm{a}}$ & $2.05^{\mathrm{a}}$ & $2.02^{\mathrm{a}}$ & $1.98^{\mathrm{a}}$ & $2.05^{\mathrm{a}}$ & $2.0^{\mathrm{a}}$ & $2.05^{\mathrm{a}}$ & $2.06^{\mathrm{a}}$ & $2.02^{\mathrm{a}}$ \\
\hline Carbohydrate $^{1}$ & $17.10^{\text {de }}$ & $18.54^{\mathrm{b}}$ & $16.54^{\mathrm{f}}$ & $18.77^{\mathrm{a}}$ & $16.37^{\mathrm{f}}$ & $18.56^{\mathrm{b}}$ & $17.74^{\mathrm{c}}$ & $17.2^{\mathrm{de}}$ & $17.32^{\mathrm{d}}$ \\
\hline Lactose $^{1}$ & $6.19^{\mathrm{a}}$ & $4.57^{\mathrm{d}}$ & $5.47^{\mathrm{b}}$ & $4.57^{\mathrm{d}}$ & $6.09^{\mathrm{a}}$ & $3.97^{\mathrm{e}}$ & $4.54^{\mathrm{d}}$ & $5.11^{\mathrm{c}}$ & $5.27^{\mathrm{c}}$ \\
\hline Lipids $^{1}$ & $1.77^{\mathrm{a}}$ & $1.55^{\mathrm{c}}$ & $1.46^{\mathrm{c}}$ & $1.18^{\mathrm{e}}$ & $1.65^{\mathrm{b}}$ & $1.31^{\mathrm{d}}$ & $1.74^{\mathrm{ab}}$ & $1.32^{\mathrm{d}}$ & $1.48^{\mathrm{c}}$ \\
\hline Energy Value $^{3}$ & $92.61^{\mathrm{d}}$ & $96.27^{\mathrm{a}}$ & $87.39^{\mathrm{g}}$ & $93.57^{c}$ & $88.54^{\mathrm{f}}$ & $94.1^{b c}$ & $94.86^{\mathrm{b}}$ & $89.00^{\mathrm{f}}$ & $90.72^{e}$ \\
\hline $\mathrm{Na}^{2}$ & $68.31^{\mathrm{a}}$ & $56.71^{\mathrm{e}}$ & $61.17^{\mathrm{b}}$ & $52.5^{\mathrm{g}}$ & $60.44^{\mathrm{c}}$ & $58.30^{\mathrm{d}}$ & $49.94^{\mathrm{i}}$ & $54.7^{\mathrm{f}}$ & $51.76^{\mathrm{h}}$ \\
\hline $\mathrm{K}^{2}$ & $78.25^{e}$ & $80.85^{\mathrm{d}}$ & $89.92^{\mathrm{a}}$ & $76.04^{\mathrm{f}}$ & $64.72^{\mathrm{g}}$ & $87.42^{\mathrm{b}}$ & $80.75^{\mathrm{d}}$ & $76.20^{\mathrm{f}}$ & $83.05^{c}$ \\
\hline $\mathrm{Ca}^{2}$ & $3.55^{\mathrm{b}}$ & $3.42^{\mathrm{bc}}$ & $3.76^{\mathrm{ab}}$ & $3.15^{\mathrm{d}}$ & $3.75^{\mathrm{ab}}$ & $3.29^{\mathrm{cd}}$ & $3.86^{\mathrm{a}}$ & $2.86^{\mathrm{e}}$ & $2.78^{\mathrm{e}}$ \\
\hline $\mathrm{Cu}^{2}$ & $0.62^{c}$ & $1.46^{\mathrm{a}}$ & $0.95^{\mathrm{b}}$ & $0.59^{c}$ & $0.43^{\mathrm{de}}$ & $0.40^{\mathrm{e}}$ & $0.53^{\mathrm{cd}}$ & $0.40^{\mathrm{e}}$ & $0.52^{\text {cde }}$ \\
\hline $\mathrm{Fe}^{2}$ & $0.02^{\mathrm{a}}$ & $0.03^{\mathrm{a}}$ & $0.03^{\mathrm{a}}$ & $0.00^{\mathrm{b}}$ & $0.00^{\mathrm{b}}$ & $0.00^{\mathrm{b}}$ & $0.00^{\mathrm{b}}$ & $0.00^{\mathrm{b}}$ & $0.03^{\mathrm{a}}$ \\
\hline $\mathrm{Zn}^{2}$ & $0.19^{\mathrm{de}}$ & $0.48^{\mathrm{a}}$ & $0.41^{\mathrm{b}}$ & $0.25^{\mathrm{d}}$ & $0.37^{\mathrm{bc}}$ & $0.28^{\mathrm{cd}}$ & $0.24^{\mathrm{de}}$ & $0.17^{\mathrm{e}}$ & $0.35^{c}$ \\
\hline $\mathrm{Mn}^{2}$ & $0.05^{\mathrm{b}}$ & $0.11^{\mathrm{a}}$ & $0.06^{\mathrm{b}}$ & $0.12^{\mathrm{a}}$ & $0.08^{\mathrm{b}}$ & $0.15^{\mathrm{a}}$ & $0.08^{\mathrm{b}}$ & $0.08^{\mathrm{b}}$ & $0.11^{\mathrm{a}}$ \\
\hline $\mathrm{Mg}^{2}$ & $0.01^{\mathrm{a}}$ & $0.01^{\mathrm{a}}$ & $0.01^{\mathrm{a}}$ & $0.01^{\mathrm{a}}$ & $0.01^{\mathrm{a}}$ & $0.01^{\mathrm{a}}$ & $0.01^{\mathrm{a}}$ & $0.01^{\mathrm{a}}$ & $0.01^{\mathrm{a}}$ \\
\hline
\end{tabular}

${ }^{1} \mathrm{~g}(100 \mathrm{~g})^{-1}$ (wet basis); ${ }^{2} \mathrm{mg}(100 \mathrm{~g})^{-1}$ (wet basis); ${ }^{3} \mathrm{kcal}(100 \mathrm{~g})^{-1}$; T1: $10 \%$ of RRE and $30 \%$ of W, T2: $10 \%$ of RRE and 50\% of W, T3: 30\% of RRE and 30\% of W, T4: 30\% of RRE and 50\% of W. T5: 6\% of RRE and 40\% of W, T6: $34 \%$ of RRE and 40\% of W, T7: $20 \%$ of RRE and $26 \%$ of W, T8: $20 \%$ of RRE and 54\% of W. T9: $20 \%$ of RRE and 40\% of W. a-i Means in same row not sharing a common superscript are different $(\mathrm{p}<0.05)$. 
present study can be considered as low Na content, because they have a composition lower than $120 \mathrm{mg}(100 \mathrm{~g})^{-1}$ or $(100 \mathrm{~mL})^{-1}$. This result is in line with the global recommendations made by the World Health Organization to reduce sodium intake (World Health Organization, 2012) and also with the voluntary agreement to reduce the sodium content of processed products, made between the Ministry of Health and associations that represent the food industry companies in Brazil that foresees the reduction of the ingredient in dairy products, sausages and ready meals (Brasil, 2013b).

The Ca contents were lower than the values found by Tarantola \& Wujastyk (2009) in rice-based commercial beverages, between 20 and $350 \mathrm{mg}(100 \mathrm{~g})^{-1}$. Because of the low Ca content, the present study showed that the produced beverages cannot be consumed as a Ca source or a substitute for milk and that $\mathrm{Ca}$ should be obtained from other food sources or the beverages should be augmented with Ca.

According to the evaluations of the applied physicochemical properties, it was verified that the fermented milk drinks enriched with red rice extract and whey have a great nutritional and functional benefits, and maybe another alternative for the consumer. Given the variability of the beverages developed there is a need for future studies considering the sensory quality through the application of projective techniques as the studies of Pinto et al. (2018) and other innovative methods based on consumer perception as the work of Esmerino et al. (2017).

According to the principal component analyses for the physicochemical properties of the fermented dairy beverages added with red rice extract observed in Figure 2, the treatments were divided into four groups with different attributes.

Group I is formed by $\mathrm{T} 1$ that contains the highest ash $(0.58 \%)$, lipid (1.77\%), protein (2.06\%), lactose (6.19\%) and acidity contents ( $0.62 \mathrm{~g}$ per $100 \mathrm{~g}$ of lactic acid). The $\mathrm{pH}$ was 4.33 , the

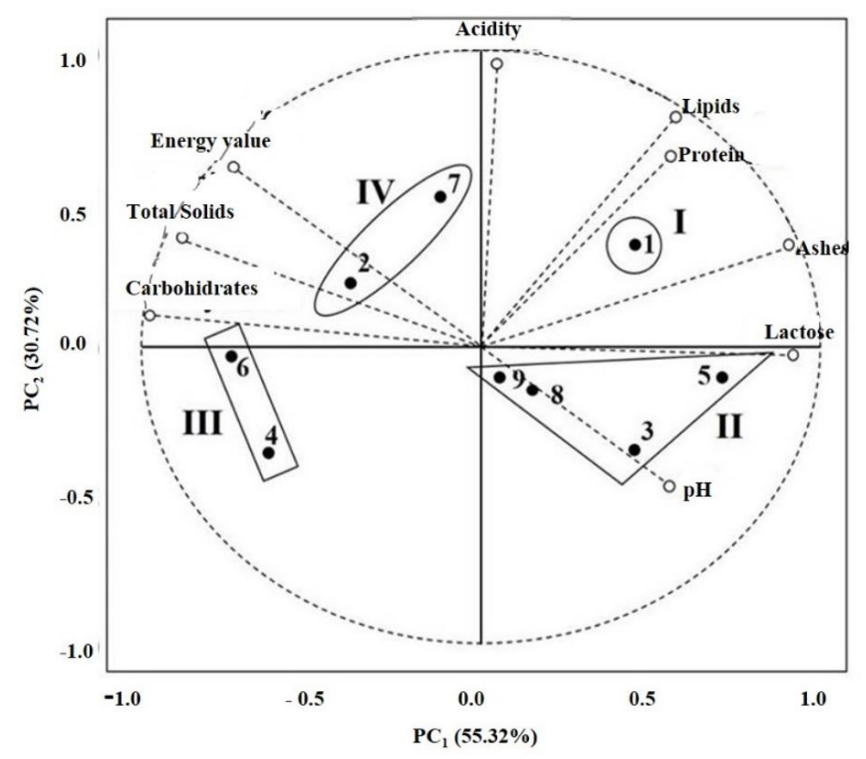

Figure 2. Principal components analyses of the physicochemical analysis of fermented dairy beverages augmented with red rice extract. carbohydrates and total solids were 17.1 and $21.52 \%$, respectively, and every $100 \mathrm{~g}$ of this beverage provides an energy value of $92.61 \mathrm{kcal}$. The characteristics of T1 most likely result from its higher content of milk, with $45 \%$ more milk than treatment T8, which is the formulation with the lowest milk content in the composition. This difference leads to higher values of the nutrients in $\mathrm{T} 1$ compared to the other groups because milk is rich in these nutrients.

Treatments T3, T5, T8 and T9, which form Group II, are characterized by the highest mean $\mathrm{pH}$ values (4.34) and lowest carbohydrate contents (17\%) and, accordingly, the lowest titratable acidity values ( $0.55 \mathrm{~g}$ per $100 \mathrm{~g}$ of acid acid), providing the lowest total solid values (21\%) and energy value of $89 \mathrm{kcal}$ per $100 \mathrm{~g}$ of beverage. The mean ash, lipid, protein and lactose contents were $0.6 \%, 1.5 \%, 2.0 \%$ and $5.5 \%$, respectively.

Treatments T4 and T6 formed Group III and had the lowest ash $(0.5 \%)$, lipid (1.3\%), protein $(2.0 \%)$ and lactose contents (4.27 g per $100 \mathrm{~g}$ of beverage), and the highest carbohydrate (18.7\%) and total solid (22.4\%) contents, with an energy value of $93.84 \mathrm{kcal}$ per $100 \mathrm{~g}$ of beverage. The $\mathrm{pH}$ and titratable acidity were 4.3 and $0.6 \mathrm{~g}$ per $100 \mathrm{~g}$ of lactic acid, respectively. This pattern is justified by the fact that such treatments contain higher red rice extract contents in their composition, i.e., higher carbohydrate contents, and also contain lower dairy base contents in their formulation, thus decreasing the ash, lipid, protein and lactose contents, which are the main components of the dairy base.

Group IV was formed by treatments T2 and T7. This group had the highest energy value of approximately $96 \mathrm{kcal}$ per $100 \mathrm{~g}$ of beverage as well as high carbohydrate (18\%) and total solids contents (23\%). The ash, lipid, protein and lactose contents were $0.53,1.65,2.05$ and $4.56 \%$, respectively. The $\mathrm{pH}$ and titratable acidity were 4.28 and $0.61 \mathrm{~g}$ per $100 \mathrm{~g}$ of lactic acid.

Regarding the physicochemical properties of the identified groups, any of them could be considered adequate because they meet the identity and quality requirements for fermented dairy beverages (Brasil, 1998).

The beverages prepared contained between 16.37 and $18.77 \mathrm{~g}(100 \mathrm{~g})^{-1}$ of carbohydrates, of which 3.98 to $6.19 \mathrm{~g}(100 \mathrm{~g})^{-1}$ were lactose. The beverages had protein contents between 1.98 and $2.06 \mathrm{~g}(100 \mathrm{~g})^{-1}$ and lipid contents between 1.18 and $1.77 \mathrm{~g}\left(100 \mathrm{~g}^{-1}\right.$ and were considered to have higher protein content than the value established by law, in addition to being partially skimmed beverages. Regarding their nutritional composition, any of the four groups formed by PCA could be considered adequate for consumption because they met the identity and quality requirements of fermented dairy beverages.

According to the principal component analyses for minerals in the fermented dairy beverages added with red rice extract observed in Figure 3, the treatments were divided into three groups with different attributes.

Group I, containing only T2, had the highest mean contents of $\mathrm{Zn}\left(0.48 \mathrm{mg}(100 \mathrm{~g})^{-1}\right), \mathrm{Cu}\left(1.46 \mathrm{mg}(100 \mathrm{~g})^{-1}\right), \mathrm{Fe}\left(0.027 \mathrm{mg}(100 \mathrm{~g})^{-1}\right)$, $\mathrm{K}\left(80.85 \mathrm{mg}(100 \mathrm{~g})^{-1}\right)$ and $\mathrm{Mg}\left(0.010 \mathrm{mg}(100 \mathrm{~g})^{-1}\right)$. The $\mathrm{Mn}, \mathrm{Ca}$ and $\mathrm{Na}$ values for the treatments of Group I were intermediary, 


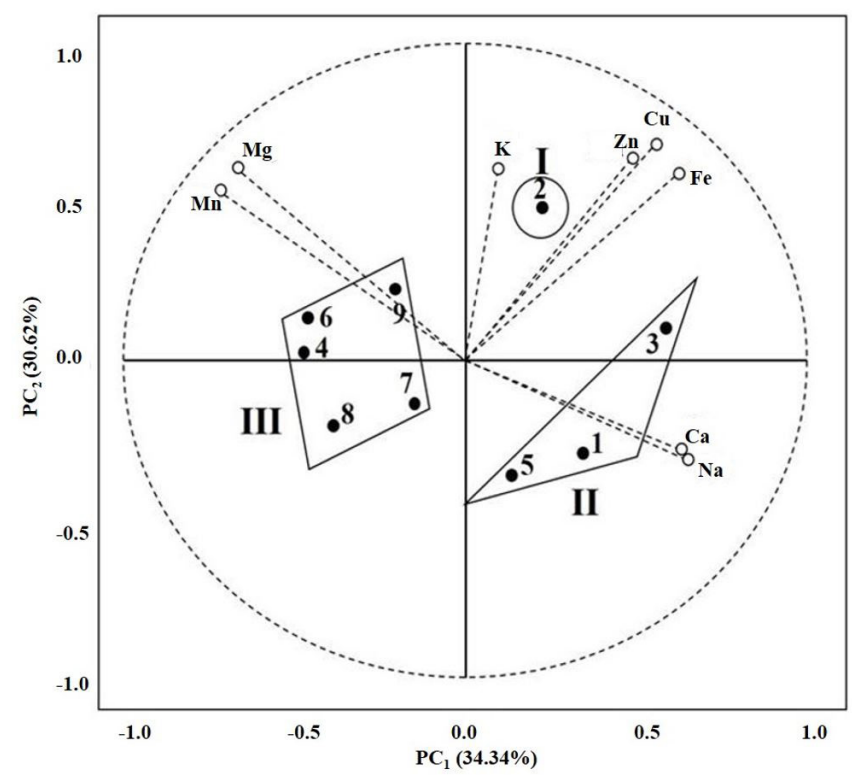

Figure 3. Principal components analysis for minerals in fermented dairy beverages added with red rice extract.

with the following results: $0.106,3.42$ and $56.71 \mathrm{mg}(100 \mathrm{~g})^{-1}$, respectively.

Treatments T1, T3 and T5 formed Group II, characterized by the highest mean values of $\mathrm{Na}\left(63.31 \mathrm{mg}(100 \mathrm{~g})^{-1}\right)$ and $\mathrm{Ca}\left(3.69 \mathrm{mg}(100 \mathrm{~g})^{-1}\right)$ and the lowest mean values of $\mathrm{Mn}\left(0.064 \mathrm{mg}(100 \mathrm{~g})^{-1}\right), \mathrm{Mg}\left(0.0077 \mathrm{mg}(100 \mathrm{~g})^{-1}\right)$ and $\mathrm{K}\left(77.63(100 \mathrm{~g})^{-1}\right)$. This pattern most likely occurred because these treatments have the lowest contents of red rice extract. The values of $\mathrm{Zn}, \mathrm{Cu}$ and $\mathrm{Fe}$ for the treatments in Group II were $0.32,0.67$ and $0.015 \mathrm{mg}(100 \mathrm{~g})^{-1}$, respectively.

Group III, formed by treatments T4, T6, T7, T8 and T9, contained, in general, the lowest contents of $\mathrm{Na}\left(53.44 \mathrm{mg}(100 \mathrm{~g})^{-1}\right)$, $\mathrm{Ca}\left(3.19 \mathrm{mg}(100 \mathrm{~g})^{-1}\right), \mathrm{Fe}\left(0.0057 \mathrm{mg}(100 \mathrm{~g})^{-1}\right), \mathrm{Zn}\left(0.26 \mathrm{mg}(100 \mathrm{~g})^{-1}\right)$ and $\mathrm{Cu}\left(0.49(100 \mathrm{~g})^{-1}\right)$ and the highest contents of $\mathrm{Mn}\left(0.11 \mathrm{mg}(100 \mathrm{~g})^{-1}\right)$ and $\mathrm{Mg}\left(0.009 \mathrm{mg}(100 \mathrm{~g})^{-1}\right)$. The $\mathrm{K}$ content for the treatments of Group III was $80.68 \mathrm{mg}(100 \mathrm{~g})^{-1}$.

Considering the RDI of minerals for beverages, group I would not be considered adequate because it surpasses the recommended $\mathrm{Cu}$ contents. Group III could be considered the most adequate group for having the lowest $\mathrm{Cu}$ values in its composition.

The addition of red rice extract to the fermented dairy beverages provided considerable $\mathrm{Zn}, \mathrm{Mn}$ and $\mathrm{Cu}$ values, i.e., 2.5 to $6.83 \%$ of the RDI of $\mathrm{Zn}, 2.13$ to $6.33 \%$ of the RDI for $\mathrm{Mn}$ and 44.3 to $162 \%$ of the RDI for $\mathrm{Cu}$ for the human diet. The other studied minerals, such as $\mathrm{K}$ and $\mathrm{Fe}$, showed values similar to other dairy beverages, with up to $0.21 \%$ of the RDI for $\mathrm{Fe}$. With regards to $\mathrm{Na}, \mathrm{Mg}$ and $\mathrm{Ca}$, the beverages provided low values, i.e., between 2.08 and $2.85 \%$ of the RDI for $\mathrm{Na}$, between 0.003 and $0.004 \%$ of the RDI for $\mathrm{Mg}$ and between 0.28 and $0.38 \%$ for $\mathrm{Ca}$, and in this case, the beverages can be enriched with these minerals. Considering the RDI of minerals in this beverage, the treatments that contain between 20 and $34 \%$ of red rice extract and $26 \%$ to $54 \%$ of whey could be considered the most adequate because they contain the lowest $\mathrm{Cu}$ values in their composition.

In the analysis of the total viable count (TVC) of bacteria from the Coliform group, the estimated result for coliforms was $<3.0 \mathrm{MPN} \mathrm{mL}^{-1}$ in the recently processed dairy beverage and during the (40 days of storage) under refrigeration. The absence of total and thermotolerant coliforms, Staphylococcus spp. and Salmonella in the final product and during the entire shelf life of the experimental dairy beverages is also an indication of the good hygienic-sanitary conditions during the beverage-preparation process.

The total count of viable cells of lactic bacteria for all the studied treatments and during the entire storage time, i.e., 40 days, was higher than $10^{9} \mathrm{CFU} \mathrm{mL}^{-1}$, a result higher than the minimum limit of $10^{6} \mathrm{CFU} \mathrm{mL}^{-1}$ established by the Brazilian legislation, indicating that these specific microorganisms are viable, active and abundant in the final product and during its entire shelf life (Brasil, 2005a).

\section{Conclusion}

According to the evaluations of the applied physicochemical and microbiological properties, it was verified that the fermented milk drinks enriched with $20 \%$ to $34 \%$ of red rice extract and $26 \%$ to $54 \%$ of whey are considered more suitable for consumption because have a great nutritional and functional benefits, and may be another alternative for the consumer. Increasingly demanding, since this drink has the differential of not using colorings, flavorings, preservatives, use of an exotic product, such as red rice. It was possible to make feasible the use of co-products that can minimize waste production, prevent nutrient loss, reduce waste treatment costs, increase revenue.

Moreover, with the results obtained in the study, it is possible to say that the developed drink can be consumed up to 28 days under refrigeration, has an absence of pathogenic microorganisms and a high number of viable dairy bacteria, an advantage for the consumer. Developed beverages are also partially skimmed, with considerable protein, zinc, manganese, and low sodium content. These drinks could also be consumed by celiac patients because red rice is gluten-free.

\section{References}

American Public Health Association - APHA. (2001). Compendium of methods for the microbiological examination of foods (4th ed.). Washington: American Public Health Association.

Arsic, S., Bulatovic, M., Zaric, D., Kokeza, G., Subic, J., \& Rakin, M. (2018). Functional fermented whey-carrot beverage-qualitative, nutritive and techno-economic analysis. Romanian Biotechnological Letters, 23(2), 13496-13504.

Ascheri, D. P. R., Boêno, J. A., Bassinello, P. Z., \& Ascheri, J. L. R. (2012). Correlation between grain nutritional content and pasting properties of pre-gelatinized red rice flour. Ceres, 59(1), 16-24. http://dx.doi. org/10.1590/S0034-737X2012000100003.

Association of Official Analytical Chemists - AOAC. (2005). Official methods of analysis of Association of Official Analytical Chemists International (18. ed.). Gaithersburg: AOAC International. 
Bakr, I. A., Mohamed, T. H., Tammam, A. A., El-Gazzar, F. E. (2017) Characteristics of Yoghurt Fortified with Black Cumin Honey. Assiut Journal of Agricultural Sciences, 48(1): 67-79.

Brandelli, A., Daroit, D. J., \& Correa, A. P. F. (2015). Whey as a source of peptides with remarkable biological activities. Food Research International, 73, 149-161. http://dx.doi.org/10.1016/j. foodres.2015.01.016.

Brasil, Ministério da Saúde. Agência Nacional de Vigilância Sanitária. (1998, Janeiro 16). Regulamento Técnico referente à Informação Nutricional Complementar (declarações relacionadas ao conteúdo de nutrientes) (Portaria $n^{\circ} 27$, de 13 de janeiro de 1998). Diário Oficial [da] República Federativa do Brasil.

Brasil, Ministério da Saúde. Agência Nacional de Vigilância Sanitária. (2001, Janeiro 10). Regulamento técnico sobre padrões microbiológicos para alimentos (Resolução $n^{\circ} 12$, de 02 de janeiro de 2001). Diário Oficial [da] República Federativa do Brasil, pp. 45- 53. seção 1.

Brasil, Agência Nacional de Vigilância Sanitária. (2003, Dezembro 26). Aprova regulamento técnico sobre rotulagem nutricional de alimentos embalados, tornando obrigatória a rotulagem nutricional (Resolução RDC n 360, de 23 de dezembro de 2003). Diário Oficial [da] República Federativa do Brasil.

Brasil, Secretaria de Inspeção de Produto animal. (2005a, Agosto 24). Aprova o Regulamento Técnico de Identidade e Qualidade de Bebidas Lácteas (Instrução Normativa n 16, de 23 de agosto de 2005). Diário Oficial [da] República Federativa do Brasil, seção 1.

Brasil, Ministério da Saúde. Agência Nacional de Vigilância Sanitária. (2005b, Setembro 23). Regulamento técnico sobre a ingestão diária recomenda. IDR de proteína, vitaminas e minerais (Resolução RDC $\mathrm{n}^{\circ} 269$, de 22 de setembro de 2005). Diário Oficial [da] República Federativa do Brasil.

Brasil, Ministério da Agricultura, Pecuária e Abastecimento, Secretaria de Inspeção de Produto animal. (2007, Outubro 24). Adota o Regulamento Técnico de Identidade e Qualidade de Leites Fermentados (Instrução Normativa, de ${ }^{\circ} 46$, de 23 de outubro de 2007). Diário Oficial [da] República Federativa do Brasil, seção 1.

Brasil, Ministério da Agricultura, Pecuária e Abastecimento. (2011, Dezembro 30). Aprova o Regulamento Técnico de Produção, Identidade e Qualidade do Leite tipo A, o Regulamento Técnico de Identidade e Qualidade de Leite Cru Refrigerado, o Regulamento Técnico de Identidade e Qualidade de Leite Pasteurizado e o Regulamento Técnico da Coleta de Leite Cru Refrigerado e seu Transporte a Granel, em conformidade com os Anexos desta Instrução Normativa (Instrução Normativa no 62, de 29 de dezembro de 2011). Diário Oficial [da] República Federativa do Brasil, seção 1.

Brasil, Ministério da Agricultura, Pecuária e Abastecimento. (2013a, Abril 11). Submete à consulta pública, pelo prazo de 30 (trinta) dias, o Projeto de Instrução Normativa e seu Anexo que estabelecem os padrões de identidade e qualidade de soro de leite (Portaria $n^{\circ} 53$, de 10 de abril de 2013). Diário Oficial [da] República Federativa do Brasil, seção 1.

Brasil, Ministério da Saúde. (2013b, Novembro 06). Anvisa vai monitorar alimentos quem devem reduzir presença de sal. Retrieved from http://portal. anvisa.gov.br/resultado-de-busca?p_p_id=101\&p_p_lifecycle $=0 \& p \_p \_$ state $=$ maximized\&p_p_mode $=$ view\&p_p_col_id $=$ column $-1 \& p \_p$ col_count=1\&_101_struts_action=\%2Fasset_publisher\%2Fview_ content\&_101_assetEntryId=236608\&_101_type $=$ content $\&$ 101_ groupId=219201\&_101_urlTitle=anvisa-vai-monitorar-alimentosquem-devem-reduzir-presenca-de-sal\&inheritRedirect=true

Buttriss, J. (2010). Nutritional properties of fermented milk products. International Journal of Dairy Technology, 50(1), 21-27. http://dx.doi. org/10.1111/j.1471-0307.1997.tb01731.x.
Cappato, L. P., Ferreira, M. V. S., Moraes, J., Pires, R. P. S., Rocha, R. S., Silva, R., Neto, R. P. C., Tavares, M. I. B., Freitas, M. Q., Rodrigues, F. N., Calado, V. M. A., Raices, R. S. L., Silva, M. C., \& Cruz, A. G. (2018). Whey acerola-flavoured drink submitted Ohmic Heating: Bioactive compounds, antioxidant capacity, thermal behavior, water mobility, fatty acid profile and volatile compounds. Food Chemistry, 263, 81-88. http://dx.doi.org/10.1016/j.foodchem.2018.04.115. PMid:29784332.

Costa, N. R., Cappato, L. P., Ferreira, M. V. S., Pires, R. P. S., Moraes, J., Esmerino, E. A., Silva, R., Neto, R. P. C., Tavares, M. I. B., Freitas, M. Q., Silveira, R. N. Jr, Rodrigues, F. N., Bisaggio, R. C., Cavalcanti, R. N., Raices, R. S. L., Silva, M. C., \& Cruz, A. G. (2018). Ohmic Heating: A potential technology for sweet whey processing. Food Research International, 106, 771-779. http://dx.doi.org/10.1016/j. foodres.2018.01.046. PMid:29579986.

Cunha, T. M., Castro, F. P., Barreto, P. L. M., Benedet, H. D., \& Prudencio, E. S. (2008). Avaliação físico-química, microbiológica e reológica de bebida láctea e leite fermentado adicionados de probióticos. Semina: Ciências Agrárias, 29(1), 103-116. http://dx.doi.org/10.5433/16790359.2008v29n1p103.

Esmerino, E. A., Tavares Filho, E. R., Carr, B. T., Ferraz, J. P., Silva, H. L. A., Pinto, L. P. F., Freitas, M. Q., Cruz, A. G., \& Bolini, H. M. A. (2017). Consumer-based product characterization using Pivot Profile, Projective Mapping and Check-all-that-apply (CATA): A comparative case with Greek yogurt samples. Food Research International, 99(Pt 1), 375-384. http://dx.doi.org/10.1016/j. foodres.2017.06.001. PMid:28784495.

Ferronato, D. D. Z., Farinã, L. O., Jorge, A. S., \& Costa, M. C. D. (2004). Avaliação dos teores de lactose em iogurtes e leites fermentados produzidos no Paraná Como subsídio para orientação nutricional para pacientes com intolerância à lactose. 21 Congresso Nacional de Laticínios: Juiz de Fora - MG. Anais... Juiz de Fora - MG.

Furtado, M. M., \& Neto, L. J. P. M. (1994). Tecnologia de queijos: Manual técnico para produção industrial de queijos. São Paulo: Dipemar.

Granato, D., Putnik, P., Bursać Kovačević, D., Santos, J. S., Calado, V., Rocha, R. S., Cruz, A. G., Jarvis, B., Rodionova, O. Y., \& Pomerantsev, A. (2018b). Trends in chemometrics: Food authentication, microbiology, and effects of processing. Comprehensive Reviews in Food Science and Food Safety, 17(3), 663-677.

Granato, D., Santos, J. S., Salem, R. D. S., Mortazavian, A. M., Rocha, R S., \& Cruz, A. G. (2018a). Effects of herbal extracts on quality traits of yogurts, cheeses, fermented milks, and ice creams: a technological perspective. Current Opinion in Food Science, 19,1-7.

Guimarães, J. T., Silva, E. K., Alvarenga, V. O., Costa, A. L. R., Cunha, R. L., Sant'ana, A. S., Freitas, M. Q., Meireles, M. A. A., \& Cruz, A. G. (2018). Physicochemical changes and microbial inactivation after high-intensity ultrasound processing of prebiotic whey beverage applying different ultrasonic power levels. Ultrasonics Sonochemistry, 44, 251-260. http://dx.doi.org/10.1016/j.ultsonch.2018.02.012. PMid:29680610.

Guimarães, J. T., Silva, E. K., Ranadheera, C. S., Moraes, J., Raices, R. S. L., Silva, M. C., Ferreira, M. S., Freitas, M. Q., Meireles, M. A. A., \& Cruz, A. G. (2019). Effect of high-intensity ultrasound on the nutritional profile and volatile compounds of a prebiotic soursop whey beverage. Ultrasonics Sonochemistry, 55, 157-164. http://dx.doi. org/10.1016/j.ultsonch.2019.02.025. PMid:30853535.

International Organization for Standardization - ISO. (1998). Microbiology of the food chain - Horizontal method for the enumeration of mesophilic lactic acid bacteria - Colony count technique at $30^{\circ} \mathrm{C}$. Switzerland: Publisher. 
Itani, T., \& Ogawa, M. (2004). History and recent trends of red rice in Japan. Nihon Sakumotsu Gakkai Kiji, 73(2), 137-147. http://dx.doi. org/10.1626/jcs.73.137.

Lima, A. V. S. C., Nicolau, E. S., Rezende, C. S. M., Torres, M. C. P., Novais, L. G., \& Soares, N. R. (2016). Characterization and sensory preference of fermented dairy beverages prepared with different concentrations of whey and araticum pulp. Semina: Ciências Agrárias, 37(6), 40114026. http://dx.doi.org/10.5433/1679-0359.2016v37n6p4011.

Lourens-Hattingh, A., \& Viljoen, B. C. (2001). Growth and survival of a probiotic yeast in dairy products. Food Research International, 34(9), 791-796. http://dx.doi.org/10.1016/S0963-9969(01)00085-0.

Madora, E. P., Takalani, T. K., \& Mashau, M. E. (2016). Physicochemical, microbiological and sensory properties of low fat yoghurt fortified with carrot powder. International Journal of Agricultural and Biological Engineering, 9(1), 118-124.

Masson, L. M. P., Rosenthal, A., Calado, V. M. A., Deliza, R., \& Tashima, L. (2011). Effect of ultra-high pressure homogenization on viscosity and shear stress of fermented dairy beverage. Lebensmittel-Wissenschaft + Technologie, 44(2), 495-501. http://dx.doi.org/10.1016/j.lwt.2010.07.012.

Patras, A., Brunton, N. P., Downey, G., Rawson, A., Warriner, K., \& Gernigon, G. (2011). Application of principal component and hierarchical cluster analysis to classify fruits and vegetables commonly consumed in Ireland based on in vitro antioxidant activity. Journal of Food Composition and Analysis, 24(1), 250-256. http://dx.doi. org/10.1016/j.jfca.2010.09.012.

Pereira, J. A., Bassinello, P. Z., Cutrim, V. A., \& Ribeiro, V. Q. (2009). Comparação entre características agronômicas, culinárias e nutricionais em variedades de arroz Branco e vermelho. Revista Caatinga, 22(1), 243-248.

Pescuma, M., Hébert, E. M., Mozzi, F., \& Font de Valdez, G. (2010). Functional fermented whey-based beverage using lactic acid bacteria. International Journal of Food Microbiology, 141(1), 73-81. http:// dx.doi.org/10.1016/j.ijfoodmicro.2010.04.011. PMid:20483186.

Pinto, L. P. F., Silva, H. L. A., Kuriya, S. P., Maçaira, P. M., Cyrino Oliveira, F. L., Cruz, A. G., Esmerino, E. A., \& Freitas, M. Q. (2018). Understanding perceptions and beliefs about different types of fermented milks through the application of projective techniques:
A case study using Haire's shopping list and free word association. Journal of Sensory Studies, 33(3), 12326-12345. http://dx.doi. org/10.1111/joss.12326.

Raghuvanshi, R. S., Dutta, A., Tewari, G., \& Suri, S. (2017). Qualitative Characteristics of Red Rice and White Rice Procured from Local Market of Uttarakhand: A Comparative Study. Journal of Rice Research, 10, 49-53.

Rohman, A., Helmiyati, S., Hapsari, M., \& Setyaningrum, D. L. (2014). Rice in health and nutrition. International Food Research Journal, 2, 13-24.

Sharma, J. K., Sharma, T. R., \& Sharma, S. K. (2012). Comparative Study on Macro and Micro Minerals Composition of Selective Red Rice Landraces from Chamba District of Himachal Pradesh-India. World Journal of Agricultural Sciences, 8(4), 378-380.

Statsoft (2007). Electronic Statistics Program (3th ed.). Tulsa: StatSoft.

Tamime, Y. A., \& Robinson, R. K. (2007). Yoghurt: Science and technology (3rd ed). Cambridge: Woodhead Publishing Ltd.

Tarantola, J., \& Wujastyk, L. (2009). Alternative Milk beverages. Journal of Renal Nutrition, 19(2), e1-e10. http://dx.doi.org/10.1053/j. jrn.2008.12.002.

Turkmen, N., Akal, C., \& Özer, B. (2019). Probiotic dairy-based beverages: A review. Journal of Functional Foods, 53, 62-75. http:// dx.doi.org/10.1016/j.jff.2018.12.004.

World Health Organization - WHO. (2012). Guideline: Sodium intake for adults and children. Geneva: WHO.

Yadav, J. S. S., Yan, S., Pilli, S., Kumar, L., Tyagi, R. D., \& Surampalli, R. Y. (2015). Cheese whey: a potential resource to transform into bioprotein, functional/nutritional proteins and bioactive peptides. Biotechnology Advances, 33(6 Pt 1), 756-774. http://dx.doi.org/10.1016/j. biotechadv.2015.07.002. PMid:26165970.

Zacarchenco, P. B., \& Massaguer-Roig, S. (2004). Avaliação sensorial microbiológica e de pós-acidificação durante a vida-de-prateleira de leites fermentados contendo Streptococcus thermophilus, Bifidobacterium longum e Lactobacillus acidophilus. Food Science and Technology, 38(4), 674-679. http://dx.doi.org/10.1590/S010120612004000400033. 